\title{
Implementation of Patil Lele Traditional Game As Ethnomathematics to Improve Student's Perspective to Mathematics
}

\section{Nuzul Putri Rahmawati, Akhsanul In'am, Mayang Dintarini}

\author{
Program Studi Pendidikan Matematika, Fakultas Keguruan dan Ilmu Pendidikan, Universitas \\ Muhammadiyah Malang \\ nuzulputry@gmail.com
}

\begin{abstract}
The aim of this research is as an effort students' perspective on mathematics and the preservation of traditional Indonesian games. As for the background of this writing, because Indonesia is a country that has a diversity of cultures, one of them is traditional games. The current of globalization in Indonesia has the effect of threatening extinction towards various traditional Indonesian games. On other hand, the problem is the majority of students consider mathematics learning is difficult and unpleasant lesson. This research takes one of the traditional Indonesian games namely patil lele to be implicated in mathematics learning. This research used descriptive qualitative research with the aim of describing, explaining, and interpreting the implementation of traditional game patil lele as ethnomatematics qualitatively using observation, documentation, and filling questionnaires and tests. The results showed that the use of patil lele games introduce students to traditional games, foster social attitudes, collaborate with students, and help students understand the concept of distance between points. After applying traditional patil lele games, students can get to know the game. By introducing this game, students can love their own culture that is Indonesian culture with their participation in preserving traditional patil lele games. The application of traditional patil lele games can reduce the abstractness of mathematics by visualizing the material of distance between points through the game. Thus, the implementation can provide a good image of mathematics subjects students' perspective
\end{abstract}

Keywords: Traditional games, Patil lele, Ethnomatematics, Students perspective, and Mathematics

\section{INTRODUCTION}

Nowadays, most of the student addicted to modern games includes online games, video games, social media and other modern games rather than selecting traditional games (Suangga, Ropi, \& Mardhiyah, 2011). It is different from traditional games which rarely found and increasingly lost eroded by globalization and the progress of the age (Pinasti, Fianto, \& Hidayat, 2015). Even today the majority of student does not know traditional games (Yudiwinata \& Handoyo, 2014). The existence of various traditional games such as sudamanda, dakon, mul-mulan, dauthik is less heard, especially among student (Rahma \& Lutfi, 2013).

Other problems shows that most of the students consider mathematics learning is a lesson that requires high understanding, relatively difficult, and uninteresting lesson for them. This problem is supported by previous research which states that this is due to the tendency to abstract the formulas shown to students (Fitroh \& Fatwa, 2018; Wicaksono 
\& Saufi, 2013; Widjajanti, 2009). That thing makes students unmotivated and uninterested in learning mathematics and have poor perspective of students on mathematics (Fitroh \& Fatwa, 2018; Sari, 2018; Anita, 2014). Anticipating these problems, the teacher must find ways that can make mathematics learning more enjoyable (Rahayu, 2016).

The implications of mathematical concepts on the problems of daily life are an important part of the process of learning mathematics (Tanujaya, Prahmana, \& Mumu, 2017). Therefore, it takes something that connects mathematics with the problems of everyday life (Abdullah, 2017). One of them can be used as a connection is culture. This is because the culture is closely related to everyday life. Culture is a whole unit that is integrated with the community (Wahyuni, 2013). Indonesia is one of the countries that have racial and ethnic diversity. Indonesia have rich culture; one of them is traditional games (Yanu, Fianto, \& Yosep, 2014). Therefore, this research raised traditional games that almost extinct to be implicated in mathematics learning. There are several of traditional games that contain elements of learning mathematics; they are engklek, gobak sodor, congklak, galah and pencle (Muzdalipah \& Yulianto, 2015). Its implementation is a engklek game on geometry of flat-build material (Irawan, 2018). Furthermore, there are dakon games that are applied to multiplication operation material, KPK and FPB (Linguistika \& Febriyana, 2011; Widiastuti, 2014).

This research implements traditional game of patil lele as ethnomatematics. Patil lele is one of hundreds of traditional Indonesian games that are played in groups. This game is played by throwing or hitting a small wooden rod called a anak patil lele with a large wooden stick called the induk patil lele. Patil lele games are usually played in the field, yard, or in a roomy area (Yanu et al., 2014; Prastowo, 2018). The purpose of this game is to compete to be superior in getting points. The points obtained come from calculating the distance between holes with the fall of a anak patil lele, which can be attributed to calculating the distance between two points in mathematics learning (Bito, 2014).

Based on these problems, the problem is only limited to the use of traditional patil lele games as learning models to improve students' perspective on mathematics and introduce traditional mathematical games to students. So, the problems in this research can be formulated as follows: 1) the use of traditional patil lele as mathematical learning model on material between points; 2) traditional game of patil lele as a learning model to improve students' perspective on mathematics, and 3) traditional game of patil lele as a learning model to introduce traditional games to students. The purpose of this research is to answer these problems.

\section{RESEARCH METHOD}

This research uses descriptive qualitative research with the aim of describing, explaining, and interpreting qualitatively the implementation of traditional game patil lele as ethnomatemathics to improve students' perspective on mathematics. The traditional game of patil lele was used as the object of research and involved ten students of VIIIF class of SMP Negeri 3 Batu as subjects of research taken randomly. Subject taking is based on the sequence of student seating by counting and taking sequences in multiples of three. The research was conducted at SMP Negeri 3 Batu in the odd semester of the academic year 2018/2019. Data collection techniques in this research 
used observation, documentation, and filling out questionnaires and tests. Observations were carried out before implementation and during the traditional patil lele game implementation. Similarly, documentation was taken when the application of traditional patil lele games was carried out. Meanwhile, filling out questionnaires and tests was carried out by players after the implementation of traditional patil lele games. Questionnaires are used to determine student responses regard to the application of traditional patil lele games in understanding the concept of distance between two points in achieving indicators of student perception. The questionnaire used was adapted Intisari in 2017 in which there are indicators of student perceptions, namely accepting, understanding, and assessing. The stages of research carried out as follows: 1) primary observation; 2) literature review; 3) preparation; 4) application, and 5) data analysis. Data analysis techniques carried out in this research are qualitative analysis. The stages of qualitative analysis include the following: 1) data reduction, namely simplifying obtained data during data mining in the field; 2) presentation of data, which presents a set of structured data that gives the possibility of taking conclusions, and 3) verification of data, namely concluding what has been analyzed at the stage of data reduction.

\section{RESULT AND DISCUSSION}

In this section presented data description and a discussion of the results of the use of traditional patil lele games presented on September 26, 2018, located at the courtyard of SMP Negeri 3 Batu. This discussion covers the results of the analysis of the use traditional patil lele games in mathematics learning on the material distance between two points. This discussion was in the form of data presentation and interrelated discussion both from the observation results in the application and evaluation after the application of traditional patil lele games.

The traditional game of patil lele required a tool consisting of two wooden slats of the same size but different lengths and a hole to put one shorter wood. The hole can also be replaced with two stones as a backing for the wood. In addition, the traditional game of patil lele requires a fairly large place like a yard. If the traditional game of patil lele is played on a field or a place that does not have a roof, then make sure the weather is clear and supports this game. The aim of this game is to determine the winning team, which is the team that gets more points than the other teams. The points are in the form of an accumulation of the distance between the wok and the hole where the wood is thrown with the point of the fall of the wood after being thrown when the team becomes a player. As for the stages in the application of traditional patil lele games in the implementation, there are three stages, they are: 1) preparation or planning stage; 2) implementation stage, and 3) evaluation stage.

At the preparation stage, the first thing was inform the students that some of them invited to play traditional patil lele games. However, students did not very interested in this game because they did not understand the rules of this traditional game and almost never hear the existence of this traditional game among them. Therefore, it was quite difficult to invite them to play traditional patil lele games. After 10 student were selected to play traditional patil lele games, players were gathered and given directions about the steps and rules for the course of the game. While a player has understood the rules and course of the game, players were asked to choose a match pair that will be the opponent of the team in the game. The playing team is grouped according to the player's play rock 
paper scissors with their partners, which were the team that wins in the rock paper scissors and the team that loses in the rock paper scissors. The team of players who win in the rock paper scissors has the right to get turn to play after preparing the tool in the form of wok, anak patil lele, and induk patil lele.

At the implementation stage of the traditional patil lele game, some students that have turn to play tried to practice how to play the game that they have understood during preparation. The student tried to throw the anak patil lele correctly before the game rules applied. Teams that got a turn to play or teams that got a turn to guard tried to achieve the victory of their respective teams by doing the following things: 1) each team tried to build each other's cohesiveness by familiarizing themselves with other team members even though in the classroom as usual not so close; 2) each team drew its own strategies, and 3 ) each team communicated and coordinated each strategy with each team member. The strategy developed by each team was like a strategy on how to throw patil lele so that the patil lele is thrown away and got more points, as well as the strategy of placing team members so they can catch the anak patil lele.

After the game lasts about ten minutes, each team understood the skills each member has in the game. Therefore, each team can developed the next strategy by using the skill roles of each member. When it has been going on quite a long time, there some of the student who seem getting bored. However, the other team members reminded each other and gave reinforcement to keep the spirit for the team's victory to be achieved together. This situation allowed the student to hold his own ego when he began to get bored in order to achieve the goal of winning the team. Every student has enthusiasm in the team's victory even though the enthusiasm various between students.

When traditional patil lele games were applied, each team was given a game activity sheet. The activity sheet was in the form of an accumulation of distance that each team got when the traditional game of patil lele takes place. The data below showed the results of worksheets for each team. 


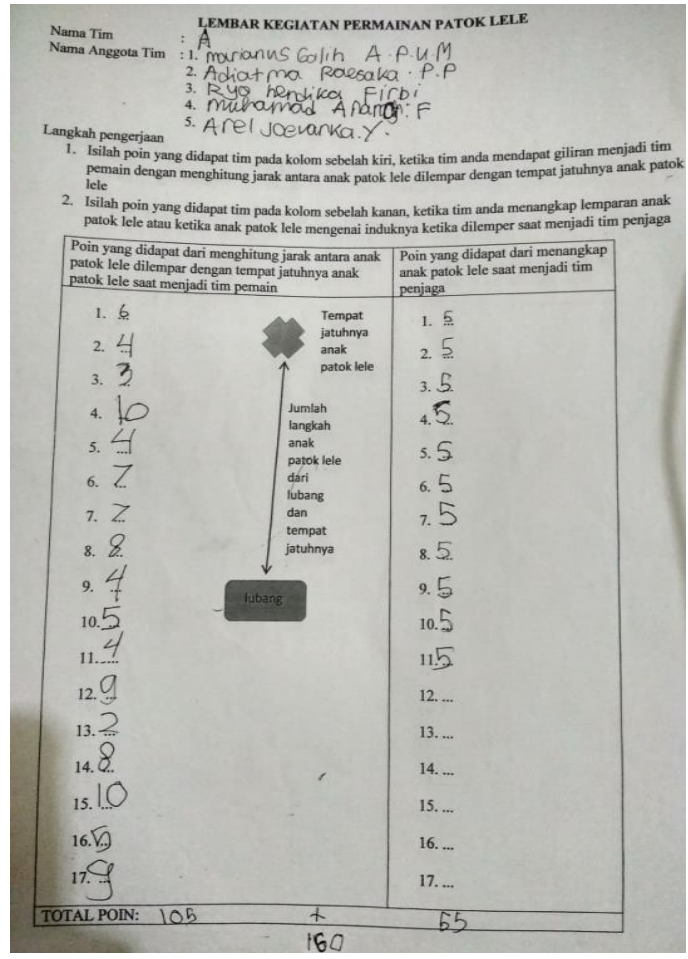

Picture 2. Activity Sheet Team A

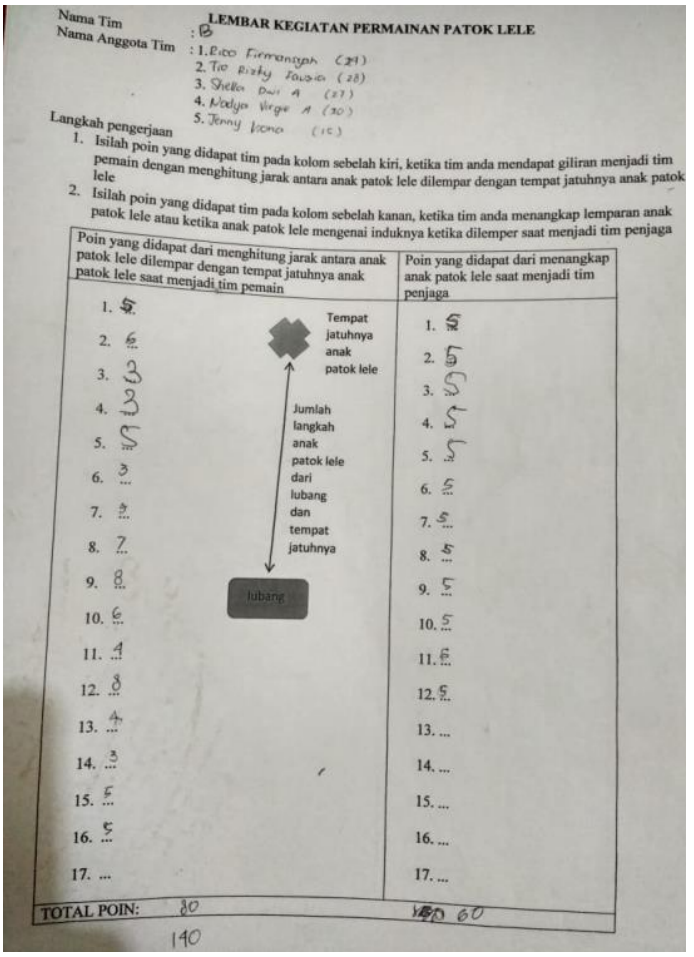

Picture 3. Activity Sheet Team B

Based on the results of the patil lele game activity sheet, it can be observed that while the team is guarded, team B gets more points in catch the anak patil lele than team A. Team B got 60 avoiding the catch of patil lele by their team members, which is 12 catch. However, team A geot 55 points from the catch of anak patil lele by their team members, which are as many as 11 catches. This is different when being a team player, team A gets more points from throwing patil lele by his team members, that was 105 points. Different from team B when became a player, team B gets fewer points than team $\mathrm{A}$, which is 80 points.

This point showed that each member in the team has their own different skills, in team A and team B. This skill that makes the basic capital in the formulation of strategies that they used in the game. Each team developed a different strategy, depending on the portion of skills each member of the team has. In determining the skills of each member of the team also requires considerable time. After they played in a long period of time, after that each team can know the skill of each member of his team.

At the evaluation stage, there were two research instruments that illustrate the results of applying this traditional patil lele game. The research instruments were in the form of questionnaires and problem practice sheets. The questionnaire sheet and question exercise sheet were given when the traditional game of patil lele was applied as a form of evaluation of the activity. A questionnaire sheet was given to measure some aspects of the indicator that had been achieved after the traditional patil lele game was applied. The aspects of achievement were aspects of understanding, perspective aspects, and social aspects. The questionnaire was in the form of a closed questionnaire with 12 statements that students had to fill based on their level of agreement with the statements. The level of agreement consists of strongly disagree, disagree, agreeing, and strongly agreeing. Meanwhile, the problem exercise sheet contains a Cartesian field with several 
points in it along with five items that describe the distance between one point and another point. The following exercise data questions along with the analysis given by students after traditional patil lele games are applied.

\begin{tabular}{|c|c|c|}
\hline Dari koordinat di bawah ini, tentukan: & Dari koordinat di bawah ini, tentukan. & $\begin{array}{lllllll}1 & 1 & 1 & 1 & 1 & 1 & 1\end{array}$ \\
\hline 1. Jarak antara titik A dan titik B adalah $C$ & Dari koordinat di bawah ini, tentukan: & Dari koordinat di bawah ini, tentukan: \\
\hline 2. Jarak antara titik B dan titik D adaláh 6 & 1. Jarak antara titik A dan titik B adalah. .4 & 1. Jarak antara titik $\mathrm{A}$ dan titik $\mathrm{B}$ adalah 4 \\
\hline & 2. Jarak antara titik $B$ dan titik $D$ adaláh. 6 & 2. Jarak antara titik $B$ dan titik $D$ adalah 6 \\
\hline $\begin{array}{l}\text { 3. Jarak antara titik } \mathrm{A} \text { dan titik } \mathrm{C} \text { adalah } \mathrm{Z} \\
\text { 4. Jarak antara titik } \mathrm{C} \text { dan titik } \mathrm{E} \text { adalah } \mathrm{O}\end{array}$ & 3. Jarak antara titik $\mathrm{A}$ dan titik $\mathrm{C}$ adalah? & 3. Jarak antara titik $\mathrm{A}$ dan titik $\mathrm{C}$ adalah ? \\
\hline $\begin{array}{l}\text { 4. Jarak antara titik } \mathrm{C} \text { dan titik } \mathrm{E} \text { adalah } 9 \\
\text { 5. Jarak antara titik } \mathrm{E} \text { dan titik } \mathrm{F} \text { adalah } \emptyset\end{array}$ & 4. Jarak antara titik $\mathrm{C}$ dan titik $\mathrm{E}$ adalah .9 & 4. Jarak antara titik $\mathrm{C}$ dan titik $\mathrm{E}$ adalah. .9 \\
\hline 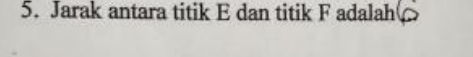 & 5. Jarak antara titik $\mathrm{E}$ dan titik $\mathrm{F}$ adalah .6 . & 5. Jarak antara titik $\mathrm{E}$ dan titik $\mathrm{F}$ adalah 6 \\
\hline Dari koordinat di bawah ini, tentukan: & Dari koordinat di bawah ini, tentukan: & Dari koordinat di bawah ini, tentukan: \\
\hline 1. Jarak antara titik $A$ dan titik B adalah .4 & Jrak antara titik A dan titik B adalah .. & 1. Jarak antara titik A dan titik B adalah. . \\
\hline 2. Jarak antara titik B dan titik D adakh 6 & 2. Jarak antara titik B dan titik D adakh & 2. Jarak antara titik B dan titik D adalah . .6 \\
\hline 3. Jarak antara titik $\mathrm{A}$ dan titik $\mathrm{C}$ adalah ... & 3. Jarak antara titik $\mathrm{A}$ dan titik $\mathrm{C}$ adalah ?? & 3. Jarak antara titik $\mathrm{A}$ dan titik $\mathrm{C}$ adalah $?$. \\
\hline 4. Jarak antara titik $C$ dan titik $E$ adalah 9 & 4. Jarak antara titik $C$ dan titik $E$ adalah 9 & 4. Jarak antara titik $\mathrm{C}$ dan titik $\mathrm{E}$ adalah 9 \\
\hline 5. Jarak antara titik $\mathrm{E}$ dan titik $\mathrm{F}$ adalah .6 & 5. Jarak antara titik $\mathrm{E}$ dan titik $\mathrm{F}$ adalah 6 & 5. Jarak antara titik $E$ dan titik $F$ adalah. 6 \\
\hline
\end{tabular}

Picture 4. The result of exercises

Based on the obtained data, the results of the problem training sheet that have been filled out by students were very satisfying. All students can fill in all the questions that have been given. It can be said that all students understood the material between points. All students answer the practice questions correctly. In other hand, there was no student mistake in answering the problem exercises. Because all students answer all the questions correctly, this showed that all students succeed in understanding the material concept of distance between two points.

In addition to practice questions, students were also required to fill out questionnaires after traditional patil lele games are applied. Based on the results of data analysis in the form of questionnaires that have been filled out by students, it explained that the questionnaire in the used of traditional game patil lele has three main indicators that must be achieved after the application of the game. The three main indicators were accepting or absorb indicators, understand, and assess. Based on these three indicators, the achievement of the success of all indicators in the questionnaire of the majority of respondents was to approve the statement in the questionnaire. It showed that the application of patil lele traditional games was very successful in achieving its achievements based on questionnaires that have been filled by students. After the traditional patil lele game applied, students understood and even play the game. This was certainly very significant for the preservation of traditional Indonesian games whose existence was threatened with extinction. By introducing this game, students can love their own culture, namely Indonesian culture with their participation in preserving traditional patil lele games. Students who previously only knew modern games such as online games, video games, social media and other modern games in their respective smartphone playstores. After followed the application of traditional patil lele games, they understood the traditional game of patil lele. Even after that, they have curiosity about other traditional Indonesian games. Not only want to know, but also want to 
understand and do other traditional Indonesian games besides traditional patil lele games. However, they did not know for sure where to find information to understand the rules of the game and how to do other traditional Indonesian games. Some of these exposures became a special achievement for the use of traditional patil lele games. This achievement was certainly very relevant to one of the objectives of this research, namely the aim of introducing and preserving Indonesian traditional games to students as the next generation of Indonesia. In addition, this achievement was also relevant to character education found in the 2013 curriculum that preserving Indonesian culture.

Most students consider mathematics learning is difficult because the students only know about series of abstract and boring formulas. The factors that influence that are mathematics itself, from within the student, and the delivery of the teacher. This was because mathematics is too abstract and far from concrete, reality, and daily life, resulting in low motivation of students to learn mathematics. In addition, teacher learning methods that do not proper of students' character and not desirable by the students also cause poor perspective of mathematics. With the application of traditional patil lele games, mathematics learning material about distance between points can be visualized in the game by calculating the distance between the origins before the anak patil lele is thrown to the point of the fall of the anak patil lele. This application can reduce the abstractness of mathematics by connecting material to the game. In addition, by using the term of "play" students will be motivated to take part in the activity, because their age still likes and needs to play. The teacher, who applied cooperative learning methods by using several games, can also change the perspectives of students towards the teacher so that students like the teacher. When students like their teacher, this can provide encouragement or a certain motivation to take part in mathematics learning. So that mathematics subjects are no longer feared by students and have a good image in the perspective of students.

Some of researchers have published the results of their research related to the implementation of several traditional games in the process of learning mathematics. However, the traditional games applied in these studies were different traditional games. Ethnomatematics linking in the application of traditional games also uses different material. Here are some of the games: 1) engklek games on geometry material on flat shapes (Irawan, 2018); 2) illustrated pat games in learning number operations (Prahmana, 2012); 3) one house game in learning number operations (Zulkardi \& Nasrullah, 2011); 4) rot play in the learning of KPK (Prahmana, 2010), and 5) top games in learning time (Jaelani, Putri, \& Hartono, 2013).

There was also one of the researchers who discussed the traditional game of patil lele in learning mathematics, although the game of patil lele was not used as a focus in the research. In that research, the use of several games was one of them traditional patil lele games. Traditional patil lele games in the research were applied to elementary school students on measurement material. The results of the research show that students realize the need of a standard measurement to get a fair measure (Wijaya, 2008). In contrast to this research, it applied traditional patil lele games to junior high school students. This application is applied to the material distance between two points. Although both were applying the traditional patil lele game and both use measurement material, but the material substance and research objectives are different. The struggles to improve the perspective of these students should be done. This is because there are previous studies which state that students' perspective can influence their learning outcomes. When 
students perceive well on math subjects, students will be motivated to learn it and improve their learning outcomes (Fitroh \& Fatwa, 2018)

\section{CONCLUSION}

Based on the results and discussion that has been presented, it can be concluded that after the traditional game of patil lele if applied in mathematics learning, it can have the following impacts: 1) introducing students to traditional Indonesian games that are almost extinct and eroded by the flow of globalization; 2) help students understand the concept of distance between points; 3) make mathematics learning fun, and 5) change the bad perspective of the students towards mathematics learning. So, it can be concluded that this research can answer the statement of problem.

\section{REFERENCES}

Abdullah, Setiawan A. (2017). Ethnomathematics in Perspective of Sundanese Culture. Journal on Mathematics Education, 8(1), 1-16. https://doi.org/10.22342/jme.8.1.3877.1-15

Anita, I. W. (2014). Pengaruh Kecemasan Matematika (Mathematics Anxiety) terhadap Kemampuan Koneksi Matematis Siswa SMP. Infinity, 3(1), 125-132. https://doi.org/http://dx.doi.org/10.22460/infinity.v3i1.43

Bito, G. S. (2014). Aktivitas Bermain sebagai Konteks dalam Belajar Matematika di Sekolah Dasar dengan Pendekatan Matematika Realistik. Jurnal Pemikiran Dan Pengembangan Sekolah Dasar Universitas Muhammadiyah Malang, 1(4).

Fitroh, M. Imam. Fatwa, Anisa. (2018). Pengaruh Persepsi Matematika terhadap Hasil Belajar Siswa di SMK Negeri 1 Surabaya. Jurnal Pembelajaran Matematika, 5(2), 148-156. Retrieved from jurnal.uns.ac.id

Intisari. (2017). Persepsi Siswa terhadap Mata Pelajaran Matematika. Journal Unsika, $1(1), 62-71$.

Irawan, A. (2018). Penggunaan Ethnomatematika Engklek dalam Pembelajaran Matematika. Jurnal MathEducation Nusantara, 1(1), 46-51.

Jaelani, A., Putri, R. I. I., \& Hartono, Y. (2013). Student's Strategies of Measuring Time Using Traditional Gasing Game in Third Grade of Primary School. Journal on Mathematics Education, 4(1).

Linguistika, Y., \& Febriyana, I. (2011). Permainan Dakonmatika Sebagai Media Pembelajaran Matematika Topik Faktor Persekutuan Terbesar ( FPB ) Dan Kelipatan Persekutuan Terkecil ( KPK ) Bagi Siswa Sekolah Dasar. Seminar Nasional Matematika Dan Pendidikan Matematika FMIPA UNY.

Muzdalipah, I., \& Yulianto, E. (2015). Pengembangan Desain Pembelajaran Matematika untuk Siswa SD Berbasis Aktivitas Budaya dan Permainan Tradisional Masyarakat Kampung Naga. Jurnal Siliwangi, 1(1), 63-74.

Pinasti, R. D., Fianto, A. Y. A., \& Hidayat, W. (2015). Penciptaan Buku Komik sebagai Upaya Pengenalan Permainan Tradisional Kepada Remaja. Jurnal ArtNouveau, 4(1), 155-162. Retrieved from http://jurnal.stikom.edu/index.php/ArtNouveau/article/view/772/364

Prahmana, R. C. I. (2010). Batu, Permen, dan Berbagi yang Adil. Majalah PMRI.

Prahmana, R. C. I. (2012). Pendesainan Pembelajaran Operasi Bilangan Menggunakan Permainan Tradisional Tepuk Bergambar untuk Siswa KELAS III Sekolah Dasar 
$(S D)$. Universitas Sriwijaya.

Prastowo, A. (2018). Permainan Tradisional Jawa sebagai Strategi Pembelajaran Berbasis Kearifan Lokal untuk Menumbuhkan Keterampilan Global di MI/SD. JMIE : Journal of Madrsah Ibtidaiyah Education, 2(1), 1-28.

Rahayu, R. (2016). Permainan Edukasi Berbasis Keunggulan Lokal dalam Pembelajaran Matematika. Prosiding Seminar Nasional "Menumbuhkan Kembali Pesona Budaya Bangsa Dalam Perspektif Psikologi.'

Rahma, R. A., \& Lutfi, A. (2013). Pemanfaatan Media Permainan Tradisional Selibur sebagai Media Pembelajaran untuk Meningkatkan Hasil Belajar Struktur Atom. Chemical Education, 2(1), 59-63.

Sari, Yunia N.I. (2018). Kontribusi Minat Belajar, Persepsi Siswa tentang Cara Mengajar Guru dan Kondisi Lingkungan Sekolah terhadap Hasil Belajar Matematika Siswa SMP.Universitas Muhammadiyah Surakarta.

Suangga, Anisa. Ropi, Helwiyah. Mardhiyah, A. (2011). Hubungan Aktivitas Bermain Video Game dengan School Myopia pada Siswa-Siswi SD Asy Syifa 1 Bandung. Ilmu Keperawatan UNPAD, 1(1), 1-15.

Sudjana, N. (2010). Dasar-Dasar Proses Belajar Mengajar. Bandung: Sinar Baru Algesindo.

Tanujaya, B., Prahmana, R. C. I., \& Mumu, J. (2017). Mathematics Instruction, Problems, Challenges and Opportunities: A Case Study in Manokwari Regency, Indonesia. World Transactions on Engineering and Technology Education, 15(3), 287-291.

Wahyuni, D. (2013). Peran Etnomatematika dalam Membangun Karakter Bangsa. Prosiding FMIPA UNY, (November), 978-979.

Wicaksono, A. B., \& Saufi, M. (2013). Mengelola Kecemasan Siswa dalam Pembelajaran Matematika. Penguatan Peran Matematika Dan Pendidikan Matematika Untuk Indonesia Yang Lebih Baik, (November), 978-979.

Widjajanti, D. B. (2009). Mengembangkan Keyakinan (Belief) Siswa terhadap Matematika Melalui Pembelajaran Berbasis Masalah. Makalah KNPM3 2009 MEN, $1-9$.

Wijaya, A. (2008). Design research in Mathematics Education: Indonesian Traditional Games as Means to Support Second graders' Learning of Linear Measurement. Utrecht University.

Yanu, A., Fianto, A., \& Yosep, S. P. (2014). Penciptaan Buku Ilustrasi Permainan Tradisional sebagai Upaya Pelestarian Warisan Budaya Lokal. Art Nouveau Journal, 3(1).

Yudiwinata, H. P., \& Handoyo, P. (2014). Permainan Tradisional dalam Budaya dan Perkembangan Anak. Paradigma, 2, 1-5.

Zulkardi, \& Nasrullah. (2011). Building Counting by Traditional Game a Mathematics Program for Young Children. Journal on Mathematics Education, 2(1). 